\title{
KEBIJAKAN SOSIAL DI PERKOTAAN SEBAGAI SEBUAH KAJIAN IMPLEMENTATIF
}

\author{
Ni Luh Putu Ening Permini \\ Fakultas Ilmu Sosial dan Ilmu Politik Universitas Mahendradatta \\ Email : enynkperminie@gmail.com
}

\begin{abstract}
Abstrak - Pada kehidupan manusia tidak lepas dari masalah sosial. Baik masalah sosial di daerah pedesaan dan juga di perkotaan. Akan tetapi, masalah sosial yang muncul kebanyakan di perkotaan daripada daerah pedesaan. Berdasarkan hal tersebut, manajemen perkotaan telah menerapkan sebagai salah satu proses manajemen untuk membuat sistem kota yang ideal seperti yang diharapkan. Fokus manajemen perkotaan erat kaitannya dengan kebutuhan aspek fisik, aspek sosial dan ekonomi masyarakat. Pola manajemennya sangat terkait dengan tingkat kompleksitas masalah yang ada di perkotaan serta terkait dengan sejumlah faktor dan tantangan, seperti penduduk, tingkat tinggi dalam urbanisasi, kemiskinan yang meningkat / minimalnya kesempatan kerja, peningkatan ketidaksetaraan sosial / kesenjangan ekonomi, menurunnya kualitas lingkungan di daerah perkotaan, dan kemampuan keterbatasan sumber daya manusia, kelembagaan dan dana untuk mengembangkan dan memelihara infrastruktur perkotaan. Kebijakan sosial pada dasarnya merupakan kombinasi dari dua kegiatan, menemukan) dan menemukan solusi untuk masalah sosial (Bessant, et al 2009: 3). Dalam hal ini, kebijakan sosial terpadu dalam kegiatan ilmiah akademik seperti penelitian yang digunakan untuk menemukan masalah sosial seperti kemiskinan, penelitian tersebut nantinya akan digunakan untuk merumuskan kebijakan. Tetapi kadang-kadang, pemerintah menunjukkan sebaliknya. Terobosan tersebut dibuat dengan sarana untuk mengantisipasi sejumlah tindakan potensial yang setiap saat menjadi ancaman. Hal tersebut masuk dalam beberapa tahap, seperti gerakan kesadaran akan persatuan di antara mereka, membuat organisasi, memperketat aturan mereka, semua yang digunakan untuk melawan intervensi petugas. Ada dua faktor yang mempengaruhi keberadaan PKL di kota Denpasar. Aspek pertama termasuk masalah melalui regulasi, sarana dan prasarana, serta manajemen sumber daya manusia. Sedangkan aspek lain adalah faktor sosial budaya dan ekonomi.
\end{abstract}

Kata kunci: masalah sosial, kebijakan sosial, regulasi , perkotaan , pedagang kaki lima

\begin{abstract}
Human being cannot separate by a social problem. There is social problem on rural and urban area. But, more problems arise in urban than rural area. Base of it, the Urban Management have implementing as a management process to make an ideal city system as like as something was expected. The focus of urban management is closely connecting with the needs of the physical aspects, social and economic aspect of communities. The pattern of its management is highly related to the level of complexity of urban problems which related to a number of factors and challenges, such as population, high level on urbanization, Poverty increasing/minimally of employment opportunities, increasing of social inequality/economic inequality, declining of environmental quality in urban area, and ability human resources limitation, institutionally and fundrising for develop and to maintain the urban infrastructure. Social policy basically is a combination of two activities, discovering) and finding a solution for social problem (Bessant, et al 2009:3). In this case, integrated social policies in the academic scientific activities such as research using to find social issue such as poverty, that research will using to policy formulating. But sometime, government showed opposite. That was a breakthrough made with the means to anticipated a number of potential act which any time become to threaten. It includes several stages, as like as movement, awareness of unity among them, make an organization, tightened them line, all of that using to fight against an intervention of the officer. There are two Factors that influence to the existence of street vendors in the city of Denpasar. First aspects including problem through regulation, facilities and infrastructure, also human resources management. Another aspects is socio-cultural and economical factors.
\end{abstract}

Keywords : social problem, social policy, regulation, urban, vendors 


\section{LATAR BELAKANG}

Usaha peningkatan kualitas sumber daya manusia dan masyarakat Indonesia yang dilakukan secara berkelanjutan dilaksanakan dengan pembangunan yang berintegrasi yang berlandaskan kemampuan nasional. Hal itu dilakukan dengan memanfaatkan kemajuan ilmu pengetahuan dan teknologi serta harus dapat memperhatikan tantangan perkembangan global. Pelaksanaannya mengacu pada kepribadian bangsa dan nilai luhur yang ditujukan untuk mewujudkan kehidupan bangsa yang berdaulat, berkeadilan, sejahtera, maju mandiri, serta kukuh terhadap kekuatan moral dan etika. Dengan demikian, membangun kesejahteraan rakyat dan ketahanan budaya merupakan agenda yang penting dan strategis yang seharusnya diikuti oleh penetapan kebijakan yang efektif. Sebagai perbandingan dengan berbagai negara di belahan dunia ini, maka Indonesia merupakan salah satu negara yang unggul dalam menetapkan suatu kebijakan ketatanegaraan yang relatif tidak tertandingi baik ditinjau dari segi penetapannya maupun dari segi masa berlakunya serta tenggang waktu dalam proses perubahannya, seperti berbagai dokumen peraturan dan kebijakan baik yang skala nasional maupun daerah. Namun dalam hal operasionalisasinya masih belum maksimal. Kesejahteraan sosial merupakan bagian tak terpisahkan dari cita-cita kemerdekaan dan muara dari agenda pembangunan ekonomi. Seperti yang tertuang Pasal 33 UUD 1945 yang merupakan pasal mengenai perekonomian dan bertujuan pada keadilan sosial bagi seluruh rakyat Indonesia. Menurut Edi Swasono dan Sri (2011), dengan menempatkan Pasal 33 UUD 1945 dan kesejahteraan sosial itu berarti pembangunan ekonomi nasional haruslah bermuara pada peningkatan kesejahteraan sosial. Namun demikian, baik pada masa Orde Baru maupun era reformasi saat ini pembangunan sosial baru sebatas jargon dan belum terintegrasi dengan strategi pembangunan ekonomi.

Penanganan masalah sosial masih belum menyentuh persoalan mendasar, program-program jaminan sosial masih bersifat parsial dan karitatif serta belum didukung oleh kebijakan sosial yang mengikat. Orang miskin masih dipandang sebagai sampah pembangunan yang harus dibersihkan. Kalaupun dibantu baru se- batas bantuan uang, barang, pakaian atau mie instant berdasarkan prinsip belas kasihan tanpa konsep dan visi serta misi yang jelas. Kalau ditelusuri lebih jauh, bahkan kini terdapat kecenderungan pemerintah kurang mengurusi permasalahan sosial. Dengan menguatnya ide liberalisme dan kapitalisme, pemerintah lebih tertarik pada bagaimana memacu pertumbuhan ekonomi setinggi-tingginya, termasuk menarik pajak yang sebesar-besarnya. Sedangkan tanggung jawab menangani masalah sosial dan memberikan jaminan sosial diserahkan sepenuhnya kepada masyarakat. Sehubungan dengan itu, bergulirnya otonomi daerah juga bukannya semakin memperkuat komitmen pemerintah daerah untuk lebih memperhatikan masyarakat kelas bawah. Pemberian wewenang yang lebih besar kepada pemerintah daerah dalam mengelola pembangunan daerah belum diikuti dengan penguatan piranti kebijakan dan strategi pembangunan sosial. Bahkan terdapat ironi di beberapa daerah dimana institusi-institusi kesejahteraan sosial yang sudah mapan, bukan dikembangkan melainkan dibumihanguskan begitu saja.

Demikian juga tidak sedikit pemerintah daerah yang hanya mau menerima penguatan dan peralihan wewenang dalam pengelolaan dan peningkatan sumber-sumber Pendapatan Asli Daerah (PAD), sedangkan peralihan tugas dan peran menangani Permasalahan Sosial Asli Daerah (PSAD) (Edi Suharto:56), inginnya diserahkan kepada masyarakat, lembaga-lembaga sosial dan kegamaan. Di Indonesia permasalahan sosial ditemukan baik di tingkat pedesaan maupun di perkotaan, tetapi lebih banyak peluang masalah-masalah sosial tersebut muncul di perkotaan. Olehnya itu, urban management (pengelolaan perkotaan) dilaksanakan sebagai suatu proses manajemen dari keadaan kondisi sistem kota saat ini menuju sistem kota yang dikehendaki berdasarkan pada kondisi ideal yang diharapkan. Fokus manajemen perkotaan sangat berhubungan dengan kebutuhan aspek fisik, sosial maupun ekonomi masyarakat. Pola pengelolaannya sangat terkait dengan tingkat kompleksitas permasalahan perkotaan yang terkait pada sejumlah faktor dan tantangan, seperti jumlah penduduk, tingginya arus urbanisasi, meningkatnya kemiskinan/kesempatan kerja di perkotaan, meningkatnya 
ketimpangan sosial/kesenjangan ekonomi, merosotnya kualitas lingkungan hidup di perkotaan, dan terbatasnya kemampuan sumber daya manusia, kelembagaan maupun menggalang dana untuk pembangunan dan pemeliharaan infrastruktur perkotaan. Seperti halnya di Kota Denpasar dalam hal menangani atau menyelesaikan masalah-masalah sosial, sebagai contoh penanganan Pedagang Kaki Lima (PKL), penggusuran, petugas kebersihan dan lain-lain sebagainya, kesemuanya ini sering menimbulkan masalah dalam menyelesaikannya. Aktivitas menyelesaikan masalah justru menimbulkan masalah baru. Banyaknya contoh di masyarakat yang relevan dijadikan justifikasi atau dasar bahwa implementasi kebijakan sosial dan faktor-faktor yang ada berpengaruh satu sama lain. Maka dari itu, dalam menghadapi era globalisasi maka visi, misi dan strategi kebijakan publik dan pembangunan sosial di Indonesia perlu direvitalisasi dan bukan dideligitimasi, olehnya itu dalam tulisan ini, difokuskan mengkaji tentang "Kebijakan Sosial di Kota Denpasar" yang merupakan salah kota besar di Indonesia yang sudah tentu memiliki banyak permasalahan yang berkaitan dengan berbagai aspek di bidang sosial.

\section{KERANGKA TEORITIS Analisis Kebijakan}

Kebijaksanaan menurut James E.Anderson (Solichin, 2008: 2), adalah sebagai perilaku dari sejumlah aktor (pejabat, kelompok, instansi pemerintah) atau serangkaian aktor dalam sustu bidang kegiatan tertentu, pemahaman ini terkait dengan Carl Friedrich (Budi, 2012: 16), yang menyatakan bahwa kebijaksanaan sebagai suatu arah tindakan yang diusulkan oleh seseorang, kelompok atau pemerintah dalam suatu lingkungan tertentu, yang memberikan hambatan-hambatan dan kesempatan-kesempatan terhadap kebijakan yang diusulkan untuk menggunakan dan mengatasi dalam rangka mencapai suatu tujuan, atau merealisasikan suatu sasaran atau suatu maksud tertentu. Hal ini sebenarnya menyangkut suatu dimensi yang sangat luas, karena kebijakan tidak hanya dipahami sebagai tindakan yang dilakukan oleh pemerintah, tetapi juga oleh kelompok maupun oleh individu yang ada dalam suatu komunitas dalam masyarakat.
Mengacu pada Hogwood dan Gunn, Bridgman dan Davis (2009) menyatakan bahwa kebijakan publik sedikitnya mencakup hal-hal seperti: bidang kegiatan sebagai ekspresi dari tujuan umum atau pernyataan-pernyataan yang ingin dicapai, proposal tertentu yang mencerminkan keputusan-keputusan pemerintah yang telah dipilih, kewenangan formal seperti undang-undang atau peraturan pemerintah, serta program, yakni seperangkat kegiatan yang mencakup rencana penggunaan sumberdaya lembaga dan strategi pencapaian tujuan dan juga keluaran yaitu apa yang nyata telah disediakan oleh pemerintah, sebagai produk dari kegiatan tertentu. Terkait dengan itu, Maka secara spesifik kebijakan publik menurut Robert Eyestone (Budi: 15), merupakan sebagai "hubungan suatu unit pemerintah dengan lingkungannya", hal ini sama halnya dengan Thomas R. Dye (Budi, 2012: 15), mengatakan bahwa Kebijakan publik adalah apapun yang dipilih oleh pemerintah untuk dilakukan dan tidak dilakukan.

Jika pengertian tersebut dilihat dalam konteks publik, maka analisa kebijakan publik adalah penentuan dalam rangka hubungan antara berbagai alternatif kebijakan, keputusan atau cara-cara lainnya, yang terbaik untuk mencapai sejumlah tujuan tertentu (Nagel, 2010). Rumusan ini memberikan gambaran bahwa analisa kebijakan adalah metode atau disiplin untuk mengkaji, menemukan mengenali, merumuskan permasalahan yang dihadapi, kemudian mengembangkan, menilai serta memilih kebijakan alternatif, guna memecahkan permasalahan atau tujuan yang diinginkan. Demikian juga, menurut E.S.Quide (Riant: 83), bahwa asal muasal analisa kebijakan disebabkan banyaknya kebijakan yang tidak memuaskan. Begitu banyak kebijakan yang tidak memecahkan masalah justru bahkan memunculkan masalah baru. Demikian juga Carl W. Patton dan David S. Savicky (Riant, 2012: 84), menjelaskan bahwa analisa kebijakan adalah tindakan yang diperlukan untuk dibuatnya sebuah kebijakan, baik kebijakan yang baru sama sekali atau kebijakan yang baru sebagai konsekuensi dari kebijakan yang ada. Analisa kebijakan bekerja dalam sebuah lingkungan yang serba terbatas: waktu, informasi, bahkan pengetahuan. Kegiatan analisis kebijakan merupakan suatu keha- 
rusan bagi perumusan kebijakan, namun tidak terlalu ditekankan pada implementasi kebijakan dan lingkungan kebijakan, pada implementasi kebijakan dan lingkungan kebijakan biasanya dilakukan evaluasi.

Namun demikian, evaluasi kebijakan merupakan bagian dari analisis kebijakan yang lebih bersifat berkenaan dengan prosedur dan manfaat dari kebijakan. Bentuk-Bentuk Analisis Kebijakan Publik Menurut William N. Dunn (2010), bahwa hubungan antara komponen-komponen informasi kebijakan dan metode-metode analisis kebijakan memberikan landasan untuk membedakan tiga bentuk utama analisis kebijakan, antara lain:

a. Analisis Kebijakan Prospektif

Identik dengan transformasi informasi sebelum aksi kebijakan dimulai dan diimplementasikan. Analisis ini cenderung mencirikan cara beroperasi para ekonom, analisis sistem, dan peneliti operasi. Selain itu, analisis ini seringkali menimbulkan jurang pemisah yang besar antara pemecahan masalah yang diunggulkan dan upaya-upaya pemerintah untuk memecahkan.

\section{b. Analisis Kebijakan Retrospektif}

Analisis ini sesuai dengan deskripsi penelitian kebijakan, juga dijelaskan sebagai transformasi informasi sesudah aksi kebijakan dilakukan dan mencakup berbagai tipe kegiatan yang dikembangkan oleh tiga kelompok analis, yang terdiri dari: kelompok analis yang berorientasi pada disiplin, kelompok analis yang berorientasi pada masalah dan kelompok analis yang berorientasi pada aplikasi.

c. Analisis Kebijakan yang Terintegrasi

Analisis ini merupakan bentuk kombinasi analisis antara gaya operasi para praktisi yang menaruh perhatian transformasi informasi sebelum dan sesudah tindakan kebijakan diambil. Analisis kebijakan yang terintegrasi tidak hanya mengharuskan para analis untuk mengkaitkan tahap penyelidikan retrospektif dan prospektif, tetapi juga menuntut para analis untuk terus menerus menghasilkan dan mentransformasikan informasi setiap saat. Dengan kata lain analis dapat terlibat dalam tranformasi komponen-komponen informasi kebijakan searah dengan perputaran jarum jam berulangkali sebelum akhirnya pemecahan masalah kebijakan yang memuaskan ditemukan. Analisis ini mempunyai semua kelebihan yang dimiliki oleh semua metodologi analisis retrospektif dan prospektif, tetapi tidak satupun dari kelemahan mereka. Analisis yang terintegarsi melakukan pemantauan dan evaluasi kebijakan secara terus menerus sepanjang waktu, tidak demikian halnya dengan analisis prospketif dan retrospektif yang lebih sedikit menyediakan informasi dalam berbagai hal kehidupan sosial.

\section{Kebijakan Sosial}

Kebijakan sosial adalah salah satu bentuk dari kebijakan publik. Kebijakan sosial merupakan ketetapan pemerintah yang dibuat untuk merespon isu-isu yang bersifat publik, yakni mengatasi masalah sosial atau memenuhi kebutuhan masyarakat banyak. (Bessant, Watts, Dalton dan Smith 2009:14). Kebijakan sosial merupakan kebijakan yang menyangkut masyarakat secara keseluruhan yang di dalamnya menyangkut berbagai aspek baik aspek sosial, politik, maupun aspek ekonomi. Faktor ekonomi dan politik merupakan bagian yang integral yang tidak dapat dipisahkan satu sama lainnya. Tujuan akhirnya adalah kesejahteraan sosial. Kesejahteraan sosial itu merupakan kondisi untuk mencapai kesejahteraan manusia dalam memenuhi kebutuhan baik yang bersifat material maupun non-material. Dalam arti spesifik atau sempit, kata sosial menyangkut sektor kesejahteraan sosial sebagai suatu bidang atau bagian dari pembangunan sosial atau kesejahteraan rakyat yang bertujuan untuk meningkatkan kualitas kehidupan manusia. Sebagai suatu proses, kebijakan sosial menunjuk pada tahapan perumusan kebijakan dalam kaitannya dengan variable-variabel sosial politik dan teknik metodologi.

Kebijakan sosial merupakan suatu tahapan untuk membuat sebuah rencana tindak yang dimulai dari pengidentifikasian kebutuhan, penetapan tindakan alternatif, penyeleksian strategi-strategi kebijakan. Selain itu merupakan hasil dari proses perumusan kebijakan atau perencanaan sosial, yaitu mencakup segala bentuk peraturan perundang-undangan atau proposal program yang berfungsi sebagai pedoman dalam melaksanakan berbagai kegiatan. Kebijakan sosial sebagai suatu kinerja, kebijakan sosial merupakan deskripsi atau evaluasi terhadap hasil pengimplementasian produk kebijakan sosial atau penca- 
paian tujuan suatu rencana pembangunan. Kegiatan analisis ini untuk melihat dampak atau pengaruh yang terjadi pada masyarakat, baik yang bersifat positif maupun negatif, sebagai akibat dari diterapkannya suatu peraturan perundang-undangan. Secara khusus biasanya diistilahkan dengan analisis kebijakan sosial (Quide, 2012).

\section{Model Analisis Kebijakan Sosial}

Implementasi kebijakan sosial dapat diukur melalui tiga model analisis yaitu: Prospektif, Retrospektif dan Integratif (Dunn, 2009). Selain itu, kebijakan sosial dilihat sebagai suatu kinerja sebagai dasar atau unit analisisnya, mengenai kerangka analisisnya, secara rinci dapat dilihat pada skema berikut ini.

Kerangka Analisis Kebijakan Sosial

\begin{tabular}{|c|c|}
\hline FOKUS $\longrightarrow$ PARAMETER \\
$\qquad \begin{array}{c}\text { PENELITIAN \& RA- } \\
\text { SIONALISASI NILAI- } \\
\text { NILAI POLITIK }\end{array}$ \\
\hline
\end{tabular}

\section{PEMBAHASAN}

\section{Analisis Kebijakan Sosial di Kota Den- pasar}

Kebijakan sosial yang dikaji adalah Peraturan Daerah Pemerintah Kota Denpasar tentang keberadaan Pedagang Kaki Lima (PKL) yang dinilai memang sudah tidak sesuai lagi dengan perkembangan kota dengan segala kemajuan dan perubahan yang telah terjadi. Adapun yang menjadi dasar hukum dalam pengaturan PKL di Kota Denpasar antara lain : Peraturan Daerah Kota Denpasar Nomor 3 Tahun 2000 tentang Perubahan Atas Peraturan Daerah Kota Denpasar Nomor 15 Tahun 1993 tentang Kebersihan dan Ketertiban Umum di Kota Denpasar, Peraturan Daerah Kota Denpasar No. 2 Tahun 2015 tentang Pedagang Kaki Lima, dilarang berjualan di jalan trotoar, bantaran sungai, jalur hijau, taman kota dan tempat umum, Peraturan Daerah Kota Denpasar No.1 Tahun 2015 tentang Ketertiban Umum, Peraturan Daerah Kota Denpasar No. 6 Tahun 2015 tentang Penataan dan Pemberdayaan Pedagang Kaki Lima, serta Peraturan Daerah
Kota Denpasar No. 27 Tahun 2011 tentang Rencana Tata Ruang Wilayah Kota Denpasar.

Dari kesekian regulasi yang terkait dengan keberadaan PKL, belum ada satupun yang terfokus membicarakan tentang PKL secara tersendiri. Olehnya itu, regulasi mengenai PKL perlu diadakan secara khusus dan tersendiri, termasuk di dalamnya syarat PKL yang harus dan tidak perlu membayar retribusi kepada Pemerintah Kota Denpasar, demikian pula mengenai sanksi-sanksi serta hal-hal spesifik lainnya tentang PKL tersebut. Penataan PKL merupakan bagian dari sistem pengaturan sebagaimana juga penertiban, yang digariskan dalam Peraturan Daerah Kota Denpasar No. 6 Tahun 2015 tentang Penataan dan Pemberdayaan Pedagang Kaki Lima. Oleh pihak pemerintah kota sebaiknya menindaklanjuti keputusan yang ada dalam menetapkan wilayah yang boleh dan tidak boleh ditempati dalam berdagang atau berusaha oleh para PKL.

Demikian halnya berdasarkan Peraturan Daerah Kota Denpasar No. 2 Tahun 2015 tentang Pedagang Kaki Lima, dilarang berjualan di jalan trotoar, bantaran sungai, jalur hijau, taman kota dan tempat umum. Dalam regulasi tersebut, sampai saat ini belum berjalan secara efektif, disebabkan berbagai faktor, diantaranya: terdiri dari dua: aspek eksternal terdiri dari masalah yang berkaitan dengan faktor regulasi, dan fasilitas pendukung atau Infrastruktur; serta sumber daya manusia dan manajemennya, dan aspek eksternal terdiri dari faktor sosial budaya, faktor ekonomi. Dalam proses penertiban langkah-langkah yang dilakukan Satuan Polisi Pamong Praja kota Denpasar melalui : Surat Peringatan (SP); kemudian pendekatan secara persuasif dan langkah paling akhir adalah penertiban paksa.

Secara operasional di tingkat kecamatan setidaknya menurut pengakuan mereka adalah secara garis besar hanya melakukan langkah-langkah sebagai berikut:

- Memberikan pengarahan secara langsung kepada PKL tentang masalah kebersihan.

- Dalam pembinaan PKL senantiasa dilakukan koordinasi persoalan ini dari tingkat kelurahan hingga ke tingkat Kecamatan. 
- Kewenangan yang diberikan Kecamatan kepada tingkat kelurahan hanya sebatas memberikan pengaturan.

- Hasil kerja yang dicapai dalam hal pembinaan PKL hanya sebatas dapat membangun kesadaran pada pelaku usaha PKL untuk membongkar tempat usahanya apabila lokasi yang mereka tempati diperuntukkan untuk kepentingan umum

Melihat kenyataan dalam kondisi tersebut dan ditopang oleh sumber daya manusia dengan tingkat pendidikannya yang kurang memadai, otomatis, potensi terjadinya resistensi terhadap kebijakan pemerintah besar peluangnya akan terjadi karena mereka berpikir untuk berusaha mempertahankan kepentingan hidup. Resistensi merupakan langkah perlawanan yang dilakukan olehrakyat atau masyarakat dalam rangka mempertahankan diri mereka dari kebijakan yang dianggap tidak mengakomodir kepentingannya. Resistensi oleh Alisjahbana (2009) digambarkan sebagai bentuk perlawanan yang ditempuh oleh pedagang kaki lima dengan melakukan 2 (dua) tipologi gerakan, yaitu:

- Resistensi secara terang-terangan. Gerakan ini sangat identik dengan konfrontasi, dengan melakukan cara-cara seperti berbenturan secara fisik dengan petugas, melakukan intimidasi, demonstrasi,dll.

- Resistensi tersembunyi, yakni Resistensi yang dilakukan dalam bentuk siasat untuk menghindari konfrontasi langsung dengan aparat pemerintah kota. Mereka memilih mengalah dan menghindar. Namun perlawanan ini mencoba mempertahankan kepentingannya lewat main "kucing-kucingan". Setelah ditertibkan, maka mereka akan mencari lokasi lain dan atau kembali lagi ke tempat semula, atau biasanya lebih memilih meminta bantuan advokasi dari pihak-pihak pendamping seperti mahasiswa dan Lembaga Swadaya Masyarakat (LSM).

Menurut perspektif masyarakat momentum penertiban atau dalam bahasa risetnya dikenal dengan penggusuran pedagang kaki lima selalu menghadapkan kepentingan antar pedagang kaki lima dengan Pemkot Denpasar yang kadang juga mewakili kepentingan badan-badan usaha swasta dan negara. Ironisnya, kepentingan pedagang kaki lima senantias terkalahkan ketika berhadapan dengan kepentingan pemerintah kota dan pemodal. Kenyataannya, bahwa memang ada pengakuan secara legal terhadap eksistensi PKL Kota Denpasar, yang ditandai dengan berbagai peraturan yang disahkan untuk mengatur kegiatan-kegiatan PKL. Adanya wadah/komunitas PKL dibuat sebagai sarana untuk mengantisipasi sejumlah perlakuan yang sewaktu-waktu datang mengancam mereka.

\section{KESIMPULAN}

Adapun hal-hal yang dapat disimpulkan antara lain:

a. Munculnya pusat-pusat PKL pada tempat-tempat yang dilarang, merupakan gambaran kekurangmampuan atau kekurangtegasan pemerintah kota dalam menyediakan sumber-sumber ekonomi warganya, termasuk mengatur dan menata PKL

b. Sebenarnya masyarakat formallah yang memberikan ruang kepada para PKL sejak berabad-abad lamanya, karena mereka menganggap bahwa perdagangan informal (PKL) dianggap sebagai ciri dari budaya dan tata kebiasaan diperkotaan.

c. Langkah-langkah proses penertiban yang dilakukan adalah: memberikan surat peringatan, melakukan pendekatan secara persuasif, dan terakhir melakukan penertiban secara paksa terhadap pedagang kaki lima.

d. Faktor-faktor yang berpengaruh terhadap eksistensi PKL di Kota Denpasar yaitu, dua aspek antara lain: aspek internal terdiri dari faktor regulasi, fasilitas pendukung atau infrastruktur; serta sumber daya manusia dan manajemennya. Sementara aspek eksternal terdiri dari dua faktor yaitu faktor sosial budaya dan faktor ekonomi.

\section{SARAN}

a. Sebaiknya regulasi maupun kebijakan tentang keberadaan para PKL di Kota Denpasar sangat mendesak untuk ditinjau kembali, seiring dengan adanya perubahan tentang kemajuan kota.

b. Sebaiknya pihak pemerintah Kota Denpasar tetap akan menyeimbangkan se- 
cara proporsional antara kepentingan PKL dengan kepentingan pembangunan sektor formal, Ada pemerintah kota berperan menyalurkan aspirasi para PKL, kebijakan lokalisasi di sejumlah zona, penyebaran PKL, dan sebagainya.

c. Seharusnya Pemerintah kota lebih banyak melakukan kegiatan preventif daripada represif seperti penertiban (penggusuran).

\section{REFERENSI}

Anderson, James E., Publik Policy Making, New York, Holt Rinehartand Winston, 2n dec, 2009

Bessant, Judith, Rob Watts, Tony Dalton dan Paul Smith, Talking Policy: How Social Policy in Made, Crows Nest: Allen and Unwin, 2011

Dunn, William N., Pengantar Analisis Kebijakan Publik, Yogyakarta, Gadjah mada University Press, 2012

Mustopadidjaya, AR., Analisa Kebijakan Administrasi Negara dan Administrasi pembangunan, Ujung Pandang, Temu Persadi, 2015

Nugroho D., Riant.,Kebijakan Publik (Formulasi, Implementasi, dan Evaluasi), Jakarta, Gramedia, 2014

Seidman, Ann, dkk., Penyusunan Rancangan Undang-Undang dalam Perubahan Masyarakat Yang Demokratis, Jakarta, ELIPS, 2010
Suharto, Edi., Analisis Kebijakan Publik Panduan Praktis Mengkaji Masalah dan Kebijakan sosial, Bandung, Alfabeta, 2008

, Membangun Masyarakat; Memberdayakan Rakyat: Kajian Strategis Pembangunan Kesejahteraan Sosial dan Pekerjaan Sosial, Bandung: Refika Aditama, 2008.

Solichin, Abdul Wahab, Analisis Kebijakan : Formulasi Kebijakan Implementasi Kebijakan Negara), Jakarta, Bumi Aksara, 2010

Wibawa, Samodra., Kebijakan Publik (Proses dan Analisis)., Jakarta, Intermedia, 2008. Evaluasi Kebijakan Publik, Jakarta,Rajagrafindi Persada, 2008

Winarno, Budi., Teori dan Proses Kebijakan Publik, Yogyakarta, Media Pressindo, 2009

Peraturan Daerah Kota Denpasar Nomor 3 Tahun 2000 tentang Kebersihan dan Ketertiban Umum di Kota Denpasar

Peraturan Daerah Kota Denpasar No. 2 Tahun 2015 tentang Pedagang Kaki Lima, dilarang berjualan di jalan trotoar, bantaran sungai, jalur hijau, taman kota dan tempat umum

Peraturan Daerah Kota Denpasar No.1 Tahun 2015 tentang Ketertiban Umum

Peraturan Daerah Kota Denpasar No. 6 Tahun 2015 tentang Penataan dan Pemberdayaan Pedagang Kaki Lima

Peraturan Daerah Kota Denpasar No. 27 Tahun 2011 tentang Rencana Tata Ruang Wilayah Kota Denpasar 